\title{
Mikkel Bolt
}

\section{Noises or voices: The Intelligence of the Lower Classes in Jacques Rancière}

\author{
English Summary \\ The article examines the work of the French philosopher Jacques Ran- \\ cière, that manifests itself as a series of engagements with philosophers \\ from Plato to Louis Althusser via Karl Marx. According to Rancière \\ these philoosphers all in different ways reject the lower classes' abil- \\ ity to act as political subjects and understand or create culture. In his \\ writings Rancière is able to show that the lower classes are in fact able \\ to appropriate language and culture and thereby challenge or even \\ shatter the dominant idea of culture.
}

\section{Mikkel Bolt}

Født 1973. Ph.d., adjunkt ved Institut for Kunst- og Kulturvidenskab, Københavns Universitet.

K\&K 104 (2007), 68-85 


\title{
Mikkel Bolt
}

\section{Støj eller stemmer}

\section{Om de lavere klassers intelligens hos Jacques Rancière}

\author{
»Det drejer sig om at gøre rede for konstitutionen \\ af et netværk af illegitime diskurser, der ødelægger \\ en bestemt identitet, ødelægger et bestemt forhold \\ mellem kroppene og ordene. ${ }^{1}$ \\ Jacques Rancière
}

På den intellektuelle scene i Frankrig indtager Jacques Rancière en speciel position lidt forskudt fra de mest markante tendenser, da han, bortset fra i sin tidligste ungdom, ikke har tilhørt nogen af de fremtrædende filosofiske skoler eller retninger, som har domineret den franske filosofi i de sidste 35 år. Rancière har krydset frem og tilbage mellem discipliner som filosofi, historie og pædagogik og kan ikke siges at være hverken strukturalist, marxist, dekonstruktiv eller deleuzianer. Efter at han distancerede sig fra sin læremester Louis Althusser sidst i 1960'erne - Rancière var som 25-årig med til at skrive hovedværket Lire le Capital, der udkom i 1965 - har han simpelthen været lidt ved siden af. I 1970'erne, hvor Althussers videnskabelige marxisme, begærsfilosofien og de nye filosoffer konkurrerede om at sætte dagsordenen, var Rancière begravet i arbejderarkiver, i 1980'erne hvor Lyotards postmoderne sprogfilosofi, dekonstruktion og neoliberal kantianisme var i vælten, hudflettede Rancière filosofiens hierarkiserende ulighedsdiskurs, og i 1990'erne hvor bl.a. Jean-Luc Nancy og Giorgio Agambens Heidegger-inspirerede ontologiske fællesskabsfilosofi samt Pierre Bourdieus sociologiske interventioner havde vind i sejlene, vendte Rancière sig mod filmens og kunstens metapolitiske lighedskrav. Som Alain Badiou har formuleret det, drejer det sig for Rancière om »altid at placere sig i diskursernes interval og aldrig vælge nogen af dem. ${ }^{2}$

Intervallets dynamik - denne formel kan ikke alene være en karakteristisk af Rancières tilstedeværelse på den intellektuelle scene, den kunne også stå som overskrift på hans filosofiske projekt. Uanset om han har set nærmere på 1830'ernes digtende arbejdere, Pierre Bourdieus sociologi eller filmskabere som Anthony Mann, er Rancière altid lydhør over for flakkende ord, ord der sønderriver diskursens orden. Han er fascineret af 
dem, der er i marginen af de sociale klasser. Dem, hvis stemmer ikke bliver hørt. De usynlige og dem, som ifølge filosofien ikke ved noget. Derfor bevæger Rancière sig altid imellem, imellem historie og filosofi, filosofi og politik, politik og æstetik, imellem arkivisk arbejde og filosofisk kritik. Der er således heller ikke mange af hans skrifter, der har afhandlingens form. I sine fremstillinger giver han ofte ordet til glemte eksistenser, han træder til side og lader de ekskluderede komme til orde. Rancière er ikke en 'maître à penser', han er en polemisk læser, der er lydhør over for en multiplicitet af stemmer, der traditionelt er ekskluderet fra filosofien. På den måde er han de lavere klassers filosof, der underminerer alle hierarkier i kampen for lighed. I overensstemmelse med hans kritik af filosoffens selvtildelte rolle som samfundets hoved, er der ikke noget docerende over Rancières filosofi, der snarere er aforistisk, lyrisk og ironisk. Hans fremstillinger tager ofte form gennem præsentationen af overraskende paradokser, der vender doxa på hovedet og, med Rancières egen formulering, åbner for en anden deling af det sanselige. På tværs af de mange bøger fokuserer Rancière altid på, hvorledes en gruppe fordrejer den herskende klasses sprog og derved stiller spørgsmålstegn ved den plads, gruppen er blevet tildelt i den sociale orden.

\section{»Vi er alle tyske jøder"}

Det gennemgående tema i Rancières forfatterskab er forholdet mellem viden og masserne og eksistensen af en forudgående lighed. Som Rancière har formuleret det i et interview: »Det hele begyndte med maj '68-påstanden »vi er alle tyske jøder", som er et helt igennem ideologisk udsagn, hvis validitet kun hviler på muligheden af at omvælte det politiske forhold mellem betegnelsens orden og begivenhedernes orden ved at understrege hullet, der adskiller subjekter og prædikater. Her åbnede der sig et helt felt, hvor talehandlinger forstås som politiske gestus, et felt der omformede delingen mellem ordene og tingene og samtidig omordnede distinktionen mellem legitime og illegitime talere. $\aleph^{3}$ Idet de franske studenter i maj 1968 'urimeligt' identificerer sig med tyske jøder, trækker de ifølge Rancière tæppet væk under den etablerede politiske orden og afbryder den almindelige klassifikationsmodel. Det er ikke som studerende, at de studerende mobiliserer sig politisk, det er ikke på baggrund af deres identitet. De gør det på baggrund af et hul eller mellemrum, de befinder sig pludselig uden for, mellem identiteter. De studerende udfordrer, hvad Rancière i bogen La mésentente. Politique et philosophie kalder, politi-logikken, den logik som bestemmer måden, fællesskabet er opdelt på, hvem som skal gøre hvad, for at samfundet fungerer. ${ }^{4}$ Ifølge denne logik skal 
studerende studere, arbejdere skal arbejde, franskmænd være franske. I maj '68 blev denne logik udfordret og forstyrret, politiets distribution af det sanselige blev pludselig rystet. ${ }^{5}$ I modsætning til hvad Rancières lærer, Althusser, og det franske kommunistparti påstod, så var majrevolten ifølge Rancière en virkelig politisk begivenhed, hvor politiordenens disciplinering blev afbrudt. »Den politiske aktivitet er den, som forrykker en krop fra det sted, som den var blevet anvist, eller den aktivitet, som ændrer et steds destination, den synliggør det, som ikke havde noget sted at blive set, den gør en diskurs hørbar, der hvor der kun var støj, den gør det, der ikke blev hørt som andet end støj, forståelig som diskurs. [...] Dette brud manifesterer sig gennem en serie handlinger, som omskaber rummet, hvor partierne, delene og fraværet af dele definerer sig. ${ }^{6}{ }^{6}$ I maj ' 68 flød identiteterne sammen: De studerende var tyske jøder. Der sker en afnaturalisering af de sociale relationer, det bliver pludselig synligt, at det er muligt at dele det sanselige på andre måder. Maj '68 var en afbrydelse af politilogikken, der tildeler folk bestemte pladser og roller, gør dem identiske med deres sociale funktioner. Som Rancière skriver:

»[P]olitisk aktivitet er altid en udtryksmåde, der ødelægger politiordenens deling af det sanselige ved at virkeliggøre en forudsætning, som principielt er heterogen i forhold til politiordenen, nemlig en del som ikke har en del, denne viser i sidste instans ordenens rene kontingens, ethvert talende væsens lighed med et andet talende væsen. $\ll^{7}$

Maj' 68 var ikke et udtryk for en bestemt social gruppes krav, i dette tilfælde de studerendes krav, det var snarere et brud med en sådan logik. Derfor var begivenheden en krise for det 'funktionalistiske' samfund, det samfund hvor alle har en 'naturligt' bestemt plads og alle har en funktion. Gennem den kollektive identitet (tyske jøder) synliggøres det, der ikke var synligt: de studerende som forskudte subjekter, der er i stand til at ytre sig politisk om det frelles. Der skete en risikabel subjektivering, hvor nogen tog et navn, der ikke var lokaliserbart. Som Rancière formulerer det:

»Den sociale kombattants identitet er [...] ikke et udtryk for nogen gruppes eller undergruppers 'kultur'. Den er opfindelsen af et navn for overtagelsen af bestemte talehandlinger, der affirmerer eller udfordrer en symbolsk konfiguration af forhold mellem diskursens og tingenes orden. $\ll^{8}$

Protesterne tog form af deklassificeringer, hvor grupper dukkede op, hvor 
de ikke skulle have været. Derved skiftede det politiske terræn; det var pludselig ude på gaden, at det politiske fandt sted mellem ellers adskilte og marginaliserede grupper. Statsmagtens reaktion i maj og juni 1968 var da også at forsøge at adskille studenter, arbejdere og bønder. Modreaktionens motto lød derfor også: »Arbejderne tilbage til arbejdet« og »Frankrig for franskmændene«.

Maj '68 udgjorde et brud i Rancières intellektuelle karriere, idet begivenhederne gjorde det nødvendigt for ham at distancere sig fra sin læremester Althusser, der havde afvist de studerendes og arbejdernes kritik som illegitim. Konfronteret med protesterne viste Althusser sig ifølge Rancière som den etablerede ordens filosof. Som Rancière formulerede det i sin første bog, La leçon d'Althusser fra 1974: »Den marxisme, som vi lærte i den althusserske skole, var ordenens filosofi, hvis principper adskilte os fra den revoltebevægelse, som rystede den borgerlige orden [i 1968]. «9

Rancière havde været en del af den såkaldte Cercle d'Ulm, en gruppe unge maoistiske teoretikere, som fulgte Althussers seminarer om Marx på École Normale Supérieure. ${ }^{10}$ I disse seminarer gennemførte Althusser sit angreb på den humanistiske marxisme og introducerede idéen om et epistemologisk brud mellem en ideologisk og en videnskabelig Marx; en idé som kom til udtryk gennem den skelsættende Lire le Capital. Det var denne distinktion, som Rancière i 1969 udfordrede i teksten "Sur la théorie de l'idéologie", hvor han kritiserede Althusser for at operere med et dobbelt ideologibegreb. ${ }^{11}$ I udgangspunktet definerer Althusser ideologi som en sociologisk funktion, der sikrer den sociale totalitets sammenhæng, ideologien regulerer individernes forhold til deres opgaver. Ideologien presenteres med andre ord af Althusser som en totalitet, der er mere grundlæggende end klassekampen. Men samtidig gør Althusser ideologien til den dominerende klasses våben. Som Rancière skriver:

»|I]deologien som oprindelig ikke blev presenteret som en kampscene, er i mellemtiden blevet en af kampens kombattanter. Klassekampen i ideologien, som oprindeligt var glemt, vender tilbage i en fantastisk feticheret form som klassekampen mellem ideologen $[\ldots]$ og videnskaben $[\ldots] . \ll^{12}$

Forskellen mellem ideologi og videnskab ender med at være en modsætning. Videnskaben er ikke blot anderledes end ideologien, den er »ideologiens Anden. ${ }^{13}$

Rancières kritik af Althussers begrebspar ideologi/videnskab udvides i hovedteksten i La leçon d'Althusser, hvor Rancière kommenterer Althus- 
sers Réponse à John Lewis fra 1973. I denne bog redegjorde Althusser for eksistensen af to forskellige klassekampe: på den ene side klassernes klassekamp, som imidlertid er kendetegnet ved at finde sted indhyllet $i$ historicistiske og humanistiske illusioner, og på den anden side klassekampen i teorien, hvor objektiviteten udbedrer marxismens mulige knæfald for humanisme og subjektivisme. Ifølge Rancière er denne forestilling om praksis og teori et forsøg på at skabe et rum for sig selv, for filosofien. Det epistemologiske brud skal garantere filosoffens symbolske magt. Forestillingen om historien som en proces uden et subjekt er ifølge Rancière således ikke andet end et forsøg på at skelne mellem de sande og de falske diskurser og bakke op om kommunistpartiet og dets kritik af maj '68: Protesterne var ikke en begivenhed, de var udtryk for en misforstået venstreorienteret småborgerlighed, som det var bedst, at partiet censurerede og statsmagten forbød. ${ }^{14}$

Rancières analyse er klar: Distinktionen mellem videnskab og ideologi og Althussers videnskabsbegreb gør intet andet end at retfærdiggøre videns rene væren og privilegere dem, der er i besiddelse af denne viden. »På tværs af alle hans [Althussers] tekster [...] tegner der sig en særlig figur af den teoretiske heroisme: hvis masserne kan skabe historien, er det, fordi heltene skaber teorien om den. $\ll^{15}$ Hos Althusser har masserne med andre ord ingen kreative evner, de er fanget i ideologiens sfære, fanget $\mathrm{i}$ politikkens uigennemsigtige mørke. For Althusser er det politiske det irrationelle, hvad enten det drejer sig om den samtidige politiske situation i Frankrig eller den politiske udvikling i Sovjetunionen. Stalinistisk dogmatisme har ifølge Althusser åbnet døren for subjektivisme, og hverken det franske kommunistparti eller dets intellektuelle har været i stand til at komme ud af denne irrationalisme og give et objektivt bevis for kommunismens uimodsigelighed. Modsætningen til denne irrationalitet er ifølge Althusser den marxistiske teoris revolutionære specificitet. Revolutionen er den historiske og politiske rationalitets moment, intet mindre end fornuftens inkarnation. Det er teoriens opgave at mediere mellem den almindelige politiks irrationalitet og revolutionens rationalitet. Denne forestilling gør det muligt for Althusser at undgå enhver diskussion af den samtidige politiske scene i Frankrig og i stedet pege på løsningen andre steder. Som Rancière skriver:

"Alt afhænger af denne dobbelte relation: hvis vi vil ud af den aktuelle politik, der er fanget i oppositionen mellem dogmatisme og opportunisme, må vi finde en løsning andetsteds: ved at opdage den revolutionære politiks rationalitet i aktion: Lenin i 1917 eller Mao i $1937 . \ll^{16}$ 
De revolutionære begivenheder - der altid er geografisk og historisk fjernt fra 1960'ernes Frankrig - som Althusser refererer til, kan således kun opretholde deres status som øjeblikke af ren rationalitet, hvis de bliver behandlet som rene teoretiske begivenheder uden for tid og rum. Derfor er Althussers beskrivelse af de historiske forløb i 1917 og i 1937 altid abstrakte og rent teoretiske beskrivelser, og derfor er Althusser nødsaget til at afvise protesterne i maj ' $68 .{ }^{17}$ De konkrete politiske gestus skal adskilles fra teorien. Som eksponent for den marxistiske teori, som marxismens 'maitre à penser', den der har den rette viden, må Althusser feje de nye politiske subjekters krav af bordet, de er ikke andet end ideologiske udsagn; demonstranterne og de strejkende larmer, intet andet. Althussers forsøg på at skabe en virkelig marxistisk teori gennem adskillelsen af politik og ideologi tager ifølge Rancière form af en forestilling om, at de sociale agenter ikke kan være andet end uvidende om deres eksistensforhold. For hans tidligere elev er der ikke tvivl: Når det kommer til stykket reproducerer Althussers videnskabelige marxisme idéen om, at den intellektuelle skal forklare de ulykkelige, hvorfor de i virkeligheden er undertrykte.

På sin vis løber erfaringen med Althusser og hans afvisning af maj '68 som en rød tråd gennem hele Rancières forfatterskab, der hele tiden kredser om afbrydelsen af den filosofisk meddelelse, som legitimeres af den rolle, den påstår at spille i den politiske frigørelse. I sine bøger analyserer Rancière, hvorledes de uvidende lavere klasser forsøges holdt uvidende af forskellige inkarnationer af filosofkongen: Althusser, Platon, Marx, Sartre, Bourdieu. Bruddet med Althusser var således ikke blot et brud med Althussers marxisme, det var også et brud med en bestemt måde at filosofere på. Det var et forsøg på at affirmere de parisiske studenters urimelige identifikation og forstå den som massens politiske konstitution, som demokrati. På den måde lader Rancières skrifter sig læse som et vidnesbyrd om en situation, hvor filosoffen ikke længere troner alvidende over de uvidende masser, når filosoffen har forladt sin kritiske diskurs' sikre bastion og ikke taler for de lavere klasser. Som Peter Hallward skriver, er Rancières fundamentale antagelse ganske simpel: »alle tænker, alle taler. $\ll^{18}$ Det er med udgangspunkt i denne tese, at Rancière utrætteligt kritiserer de forskellige forhindringer for udøvelsen af de lavere klassers tænkning og ironisk hudfletter de filosoffer, der, som det er tilfældet med Althusser, påstår at tale revolutionens eller demokratiets sag, men som i virkeligheden opdeler eksistensen; inddeler det der kan tænkes, høres, ses og føles og derved adskiller den marxistiske videnskab fra venstreradikalismens illusioner, adskiller acceptabel tale fra nonsens. 
Afskeden med Althusser og filosofiens autoritet fører Rancière rundt ud i krogene, ned i arkiverne og ind i discipliner som pædagogik, sociologi og xstetik. Alle steder analyserer han de mekanismer, der deler verden op og skelner mellem viden og uvidenhed, gyldig tale og uforståelige lyde. Rancière tager de simple gestus alvorligt: at se, lytte, tale og læse. ${ }^{19}$ Undervejs på denne rejse, der naturligt fører ind på læringens og pædagogikkens område, gør Rancière konsekvent op med Althussers selvprivilegerende teorier, ifølge hvilken »den pædagogiske funktion har som objekt at formidle en bestemt viden til subjekter, som ikke har denne viden. $\ll^{20}$ Sammen med sin helt, skolelæreren Joseph Jacotot, der er protagonisten i Le maître ignorant. Cinq leçons sur l'émancipation intellectuelle fra 1987, afviser Rancière den traditionelle undervisningssituations skel mellem viden og uvidenhed. »Alle intelligenser er lige. ${ }^{21}$ Konfronteret med opgaven at lære hollændere fransk uden selv at kunne hollandsk 'opdagede' Jacotot i 1818, at alle er lige intelligente, det er kun muligheden for at udvikle den enkeltes intelligens, der varierer. I modsætning til hvad Althusser skriver, så skal læreren ikke oplyse den uvidende elev. At undervise er ikke at overføre noget, man ved, til andre, som ikke ved det. Det er i stedet at anspore eleven til at opnå den viden, vedkommende ønsker. På den måde var det muligt for Jacotot, der ikke kunne et ord hollandsk, at lære hollænderne at tale fransk.

De såkaldt mindre ånder fordummes reelt af den vidende lærer, der forklarer. Den uvidende lærer, 'le maitre ignorant', derimod lader eleverne være på en sådan måde, at de af sig selv tilegner sig viden. Det vigtige bliver elevens frigørelse, at eleven bliver opmærksom på sin egen intelligens, og hvordan den kan bruges. Jacotots mission var således frigørelse: "at alle folk kan forstå deres menneskelige værdighed, blive opmærksom på deres intellektuelle evner og bestemme deres brug. «22 Det frigjorte individ frigør således ikke andre ved at videreformidle sin viden, men ved at formidle bevidstheden om, hvad det er muligt at gøre, når man opfatter sig som lige med alle andre.

\section{De skuffede teoretikere og den alt for lette kommunisme}

Kritikken af filosofiens hierarkiserende tendenser er et gennemgående greb hos Rancière; hvad enten filosofkongen hedder Althusser eller Sartre, får han ikke lov at stå uimodsagt. Selv Marx viser sig at være et eksempel på den videndes diskurs, der affærdiger de lavere klasser. Marx' voluminøse forfatterskab spreder sig i mange retninger fra journalistiske og polemiske interventioner til teoretiske analyser. Men på tværs af de mange tekster løber ifølge Rancière forsøget på at konstituere en marxistisk videnskab. 
Skuffet over 1848-revolutionen opgiver Marx de faktiske arbejdere til fordel for proletariatet som et teoretisk koncept. ${ }^{23}$ Proletariatet gøres ifølge Rancière derved til en normativ kategori, som den marxistiske videnskabsmand våger over og sammenligner de faktiske arbejdere med for at se, om de afviger fra det revolutionære projekt. Marx' utålmodighed med arbejderne i Paris - de opførte sig fjollet og småborgerligt - bliver forvandlet til en videnskab, hvor arbejderne afvises som småborgerlige, hvis de ikke lever op til forestillingen om proletariatet. I modstrid med sine emancipatoriske forhåbninger lukker Marx i virkeligheden de besiddelsesløse inde i deres mangel og tildeler sig selv rollen som den kritiske teoretiker, der ved, hvordan tingene hænger sammen, skriver Rancière. Marx ved, hvordan historien skabes, og hvem som gør det. »Menneskene 'skaber' historien, men de 'ved ikke', at de gør det. Denne formel udvikles i det uendelige " hos Marx, der iscenesætter sig selv som de uvidende arbejderes vidende filosof. ${ }^{24}$ Det er denne eksklusion af arbejderne, som Rancières lærer Althusser reproducerede små hundrede år senere med sin forestilling om modsætningen mellem ideologi og videnskab. Som Rancière skriver, eksisterer $»[\mathrm{p}]$ roletariatet [for Marx] [...] kun gennem dets indskrivning i Videnskabens Bog. ${ }^{25}$ Den videnskabelige marxisme forklarer, hvordan tingene hænger sammen. Længere er den ikke; hvorfra denne videnskab kommer, forklarer Marx ikke. Den er »alle steders uforklarlige ikke-sted. $\ll^{26}$ Når klassekampen kulminerer og river det kapitalistiske samfund fra hinanden, falder en lille del af den dominerende klasse, »bourgeois-ideologerne, som har arbejdet sig frem til en teoretisk forståelse af hele den historiske bevægelse [dvs. Marx og Engels] «, ned i proletariatet. ${ }^{27}$ Dermed er Marx' rolle sikret.

Opgaven er nu blot at sikre sig, at historien udvikler sig, som den skal. Historien udvikler sig imidlertid selvfølgelig ikke, som Marx ønsker, noterer Rancière; dér hvor proletariatet skulle have indfundet sig, dukker der i stedet komiske og tvetydige subjekter op. Problemet er simpelthen, at arbejderne ønsker tilfredsstillelse nu og her, og derfor approprierer småborgerlige forestillinger som solidaritet og broderskab i stedet for at være den negation, som Marx har dikteret, og som stemmer overens med hans teori om revolutionen. Problemet er med andre ord, at arbejderne opfører sig som om, de allerede er frigjort. Arbejderne forveksler simpelthen mål og middel, og i stedet for at negationen af arbejderen finder sted som skabelsen af proletariatet, klassen der destruerer alle klasserne, finder den sted som en forvandling af arbejderens tilstedeværelse og identitet gennem møder, samtaler og kunst. ${ }^{28}$ Der er ikke andet at gøre for Marx end at afvise denne forkerte og alt for lette kommunisme og vente. 
"At bevise over for de kommunistiske proletarer, at de ikke er kommunistiske proletarer ved at påberåbe sig et kommunistisk proletariat, hvis eneste fejl er ikke at eksistere, denne opgave er for vanskelig selv for de bedste dialektikere. Det er derfor materialisten, som tager stafetten med sin løsning, den materialistiske løsning par excellence: at vente. Det er nytteløst teoretisk at afvise disse kommunister, som ikke har nogen teori. Der er ikke andet at gøre end at sylte sagen. [...] Og vente på det kommende kommunistiske proletariat og dens organiserede bevægelse. $\ll^{29}$

I forlængelse af kritikken af læremesteren Althusser og redegørelsen for de knudrede overgange fra samtidens klassekamp til videnskabelig teori hos Marx går Rancière ved flere lejligheder i kødet på, hvad der ifølge ham er den samtidige legemliggørelse af denne hierarkiserende doxa: sociologen Pierre Bourdieu. ${ }^{30}$ Hvis det kan virke paradoksalt, at Rancière kritiserer Marx for at lukke de besiddelsesløse inde i deres mangel, så virker det umiddelbart ikke mindre 'forkert' at skyde Bourdieu i skoene, at han fastholder de lavere klasser i en subaltern position. For er Bourdieu ikke netop sociologen som minutiøst kortlægger forholdet mellem dominerede og dominerende? Jo, men Bourdieus analyse af de dominerendes og magtfuldes diskurs gør ifølge Rancière i virkeligheden ikke andet end at bekræfte den ulighed, den mener at afdække. Den store sociolog tager parti for samfundets magtesløse, taler i deres sted, forklarer hvorfor de nødvendigvis er undertrykte og ikke har adgang til uddannelse, viden og kultur. I bøgerne Les héritiers fra 1969, La réproduction fra 1970 og La distinction fra 1979 analyserer Bourdieu uddannelsessystemet som en institution til reproduktion af ulighed, hvis særlige krav og kriterier er indrettet med den hensigt at hæmme de socialt dårlige og holde dem nede. Ifølge Bourdieu er eksempelvis eksaminer og optagelsesprøver mekanismer til eksklusion og selektion, der muliggør reproduktionen og legitimerer ikke blot den kulturelle tradition, men reelt den etablerede samfundsorden. Bourdieu kritiserer således samfundets magtmekanismer, der skaber ulighed, men ifølge Rancière afviser han samtidig ethvert frigørelsesforsøg som illusorisk. De lavere klasser har ikke den rette habitus til at værdsætte kunst, længere er den ikke. Bourdieus analyser præsenterer sig på den måde som sociologiske konstateringer, sådan er det. Det er derfor, Bourdieus arbejde ifølge Rancière har så stor udbredelse. Bourdieu kritiserer systemet og bekræfter dets evighed. Der er ifølge Rancière en form for tautologi over analyseforetagendet, hvor sociologen redegør for, hvorfor de lavere klasser er ekskluderet fra uddannelsessystemet: Arbejderklasseungdommen er ekskluderet, fordi de ikke ved, hvorfor de er 
ekskluderet. Denne uvidenhed er en effekt af det system, som ekskluderer dem. Ved på denne måde at bekræfte statistikkerne - der er nogen, som er ekskluderet - bliver det muligt for sociologen at klæde sig i videnskabelige gevandter og afvise og bekræfte systemet. »Sociologen installerer sig i positionen som den evige afviser af et system, der er forsynet med evnen til for evigt at skjule sig for sine agenter. $\aleph^{31}$ Sociologen ved i modsætning til de involverede, at der er et system, og han ved, hvordan systemet fungerer. Systemet reproducerer sig i al ubemærkethed, derfor er det ikke muligt at sætte sig ud over det. At tro, at de lavere klasser kan slippe ud af denne mangel, er ikke andet end en illusion, som sociologen derfor må afvise. Rancière omskriver ironisk Bourdieu: »Det er en illusion at få dem, der ikke har den rette habitus til at værdsætte de legitime værker, til at tro, at de kan værdsætte dem. « ${ }^{32}$ Derfor er det nødvendigt, at sociologen afviser denne svigagtige kommunisme, illusionen om frigørelse, der får de lavere klasser til at tro, at de kan værdsætte og måske endda skabe kunst, med andre ord kan noget andet end det, de nu engang laver. De lavere klasser har simpelthen ikke den rette smag ifølge Bourdieu, de er ekskluderet fra 'det gode selskab' eller, med Bourdieus 'positive' termer, de er fri for forfængelighedens kult. Med denne kritik af den rene smag bekræfter Bourdieu, når det kommer til stykket, de lavere klassers mangel, han konsoliderer deres fravær og benægter, at de har mulighed for at værdsætte kunsten. Det er simpelthen ikke muligt at adskille den æstetiske sans fra dominansens rutiner, forklarer Bourdieu ifølge Rancière. De lavere klasser har ikke det, der skal til for at omgås og skabe kunst, har ikke det, der skal til for at tænke. Sociologen har på den måde skabt en position til sig selv, idet han konstaterer, at ligheden aldrig kommer.

\section{Den kulturelle kommunismes lange netter}

I overensstemmelse med kritikken af den hierarkiske mestertænkning forlader Rancière i en årrække den filosofiske fremstillingsform til fordel for en art modfilosofisk opgravningsarbejde, der er langt fra den konventionelle akademiske redegørelse. Bogen om Jacotot er ikke det eneste eksempel på en sådan praksis, i bøgerne La Parole ouvrière 1830-1851 og La nuit des prolétaires. Archives du rêve ouvrier samt i sine bidrag til tidsskriftet Les Révoltes logiques giver Rancière således ordet til arbejderne selv. ${ }^{33}$ Rancière udsætter jagten på et objektivt begreb om proletariatet til fordel for en vandring rundt i arkivets labyrinter, hvor han bl.a. finder saint-simonisterne og de kristne socialister, der udgav L'Atelier i 1840 'erne. I deres skrifter opdager han, at arbejdernes liv var langt mere forvirrende, modsætningsfyldt og komplekst end både den traditionelle 
arbejderklassehistoriografi og marxismen gør den til. Gennem Jacotot og de digtende arbejdere, han ser nærmere på i La nuit des prolétaires, finder Rancière ud af, at det mindre er viden om udbytningens mekanismer, end det er en forestilling om dem selv som værende noget andet end blot udbyttede og dominerede, der er væsentlig for de lavere klasser. Som han skriver: »[P]roletarerne skal behandles som eksistenser for hvem, der vil være flere liv. ${ }^{34}$ Det vigtige for de lavere klasser er at have en skæbne hinsides underkastelse og uvidenhed, at kunne forestille sig det, tænke det og give udtryk for det. Det er derfor, kampen for frigørelse er en intellektuel kamp, arbejderne kæmper for kulturel kommunisme, hvor »det ordinære bliver smukt som et spor efter det sande. « ${ }^{35}$ De lavere klasser kæmper for retten til at være noget andet, de kæmper for at slippe ud af den mangel, filosoffen fastholder dem i. De nægter at blive reduceret til arbejdere. Derfor er det ifølge Rancière mindre skabelsen af en egentlig arbejdertænkning, der er det vigtige, det er i stedet bevægelsen ud af det obskure mørke, hvor de er blevet placeret. Negationen af det, de nu engang er blevet sat til at gøre.

Gennem sine arkivstudier finder Rancière ud af, at denne bevægelse ofte tager form af fordrejninger af borgerskabets kultur, hvorved der åbnes et nyt rum, hvor det fælles også bliver arbejdernes anliggende. Arbejderne udstøder ikke blot udifferentierede barbariske skrig, de approprierer borgerskabets ord og publicerer pamfletter, tidsskrifter og små digtsamlinger. Når de lavere klasser giver sig til at diskutere de forhåndenværende regler, definitionerne og brugen af ordene, kommentere selve diskussionen, verificeres ligheden, som derved knyttes til det sanselige: Til det, der høres, det, der ses, og rummet, der deles. De tidligere ikke-borgere, der i politisk henseende var stumme og usynlige, kræver en plads og kræver omfordeling af det sanselige. For hvis de undertrykte ikke kunne forstå, hvad herren siger, så ville der ikke være noget hierarki. Men idet de kan forstå herrens tale, kan de også gøre oprør, konkluderer Rancière. »Uligheden er kun mulig på baggrund af intelligensernes primære lighed.« ${ }^{36}$

Idet arbejderne 'hugger' borgerskabets sprog og tænker selv, forvirrer de den traditionelle klassestruktur: De er hverken arbejdere eller borgere, de befinder sig uden for de allerede etablerede klasseidentiteter. Det er således ikke så meget en selvtilstrækkelig og ren socialistisk diskurs, der bliver skabt, som det er en blanding mellem en fremkommende arbejderidentitet og den dominerende kultur. I stedet for at hvile ud efter en urimeligt lang og hård arbejdsdag, kaster arbejderne sig over aktiviteter, de ikke burde have tid og evne til: digtning, musik og filosofi. Derved affirmerer de i en transgressiv manøvre den lighed, som Jacotot havde konstateret var en forudsætning for ethvert hierarki. De bruger deres tid 
på noget andet, end det er meningen. I en 'urimelig' og modsætningsfyldt identifikation slipper de ud af deres mangel, nøjagtig som de studerende gjorde det under majrevolten med »vi er alle tyske jøder «. Som Rancière har formuleret det i et interview fra 2000 :

"I hjertet af denne frigørelse var bruddet med den naturlige inddeling af tiden, som dikterer, at arbejderne skal arbejde om dagen og sove om natten og ikke har nogen tid tilovers til at tænke. Arbejdernes frigørelse fandt sted gennem arbejdere, som besluttede at hellige deres nætter til andre aktiviteter end søvn for at give sig selv denne tid, der ikke tilhørte dem, for at komme ind i en skriftens og tankens verden, der ikke var 'deres'. $\ll^{37}$

Arbejderne afviser, at de ikke har andet at bidrage med end deres produktive og reproduktive evner, i stedet for at hvile ud digter de og modsiger således filosofkongen, der altid konstaterer, at arbejderne ikke har tid til andet end at arbejde. »Håndværkerne, siger Platon, kan ikke beskæftige sig med de fælles anliggender, fordi de ikke har tid til at hellige sig andet end deres arbejde. De kan ikke være andetsteds, fordi arbejdet ikke venter, " som Rancière formulerer det på Platons vegne. ${ }^{38}$ Når arbejderne digter om natten, respekterer de ikke borgerskabets eksklusive ret til filosofi og kunst, arbejderne er pludselig noget andet, end de var før. De forskellige digte, artikler og sange er ifølge Rancière udtryk for en nyfundet intellektuel eksistens og ikke udtryk for eksponeringen af en autentisk arbejderklasseidentitet, som den traditionelle arbejderhistorie ellers argumenterer. Arbejderklasseproletaren er ikke en særlig eksistensmåde, det er et navn, hvorved der skabes andre subjektpositioner. Som Rancière formulerer det i Les noms de l'histoire:

»Kulturbegrebet $[\ldots]$ har kun til funktion at slette den subjektiveringsbevægelse, som er virksom i intervallet mellem flere benævnelser og dens konstitutive skrøbelighed: fraværet af kroppe i stedet for stemmer, stemmernes fravær i stedet for kroppe, spalten eller intervallet igennem hvilket historiens subjekter passerer.«39

Ved at begrænse sig til at analysere arbejderens arbejdsmæssige forhold bekræfter socialhistorien, at arbejdere ikke er andet end deres arbejde, at de kun ser verden gennem det. Rancière viser derimod, at arbejdernes modstand ikke kun har noget med arbejdernes arbejde og fag at gøre, men at den også finder sted som en stadig og aldrig afsluttet forhandling med den dominerende kulturs former. Den skabes løbende i diskussioner, 
konflikter og misforståelser mellem arbejdere, intellektuelle og andre fra borgerskabet. Arbejdsmæssig kompetence er ikke den eneste komponent i skabelsen af arbejdernes identitet, afvisning af lønarbejdet eller ønsket om at være kunstner er ligeledes en faktor og fungerer ofte som baggrund for kollektiv modstand.

De steder, hvorfra 'arbejderklassen' projiceres, er med andre ord ikke fabrikkerne, men tekster, sætninger og navne, som gør det muligt at italesætte en erfaring, som ellers var stum. 'Arbejderklasse' betegner ifølge Rancière ikke nogen præcis gruppe individer, men et brud mellem navnene og det, der er. Som en af Rancières inspirationskilder, den franske idéhistoriker Michel Foucault, udtaler i et interview fra 1977 foretaget af Rancière:

»'Pøblen' har uden tvivl ingen sociologisk realitet. Men der er helt sikkert noget i det sociale legeme, i klasserne, i grupperne, i individerne selv, som på en eller anden måde undslipper magtrelationerne. [...] 'Pøblen' eksisterer uden tvivl ikke som entitet, men der er 'noget' pøbel. Der er noget pøbel i kroppene, og i sjælene, der er noget i individerne, i proletariatet, der er noget i borgerskabet, men med en forlængelse, former, energier, forskellige irreduktibiliteter. Denne del af pøblen er mindre magtrelationernes ydre, end det er deres grænse, deres vrangside, deres tilbageslag. ${ }^{40}$

Foucaults beskrivelse af pøblen som et ubestemmeligt element, der ikke går op i magtrelationerne, men er selve magtrelationernes grænse, har fået et pertinent efterliv i Rancières filosofi, hvor pøblen altid er noget mere eller noget mindre end antaget. Pøblen eller folket overlever altid, der er altid en rest. Som Rancière udtaler i et interview: »Folk er for mig navnet på et politisk subjekt, det vil sige et supplement til enhver optællingslogik i forhold til befolkningen, dens dele og helhed. [...] Det politiske er altid et folk foruden et andet, et folk mod et folk. « ${ }^{41}$ Folket er hverken en gruppe eller en masse, men et politisk navn, et navn i en subjektiveringsakt, hvor en gruppe individer skaber et forhold mellem to subjekter, iscenesætter et brud. Filosofkongens forsøg på at føre folkets eller de lavere klassers tale tilbage til en væren eller en lokaliserbar identitet skal derfor kritiseres, da en sådan tilbageføring ifølge Rancière annullerer og forråder ordenes ubestemmelighed.

Proletariat, lighed eller tyske jøder er for Rancière eksempler på ord, som på bestemte tidspunkter flakker rundt uden krop. De er tomme og får først politisk betydning, når der rejses spørgsmål om, hvem, hvor og under hvilke omstændigheder, denne lighed skal gælde. Ordene tilhører 
ikke nogen, de er til alles disposition og kan derfor bruges til at rive det allerede etablerede fællesskab fra hinanden. Ordene forhindrer enhver stabilisering, de er til rådighed, er forældreløse. ${ }^{42}$ Ordene er ikke som hos Althusser blot en maske eller en afspejling, de stiller sig til rådighed for en polemisk brug. ${ }^{43}$ Pludselig sker der et brud, der åbner sig et hul, de lavere klasser bringes ud af deres normale stumme væren og taler med om det fælles. De er ikke længere kun destineret til at arbejde. Når politiordenen udfordres, afløser lighed radikal forskel, lighed mellem borgerne og dem, der var frarøvet talens mulighed.

Filosofkongen ser sig konfronteret med 'dårlige læsere', hvad Rancière i Les noms de l'histoire kalder litterære dyr, der gang på gang udfordrer den allerede etablerede orden og truer med at gøre filosoffen arbejdsløs. For filosoffen er der ingen tvivl, arbejderen arbejder og reproducerer sig og er derfor en del af samfundet gennem sit arbejde. »[D]e riges parti har altid sagt én ting, som helt præcist er det politiskes negation: ikke-delens del findes ikke [il n'y a pas de part des sans-part]. « ${ }^{44}$ I politifællesskabet bliver ordene brugt til at betegne objekter og påbyde bestemte handlinger. Til filosoffens store fortrydelse tænker de lavere klasser imidlertid selv, idet de som en art sproglige pirater bemægtiger sig andres ord, tanker og kultur og derved undergraver den allerede etablerede deling af det sanselige. Ordene får arbejderne til at glide ud af den identitet, de er blevet tildelt, de løsnes fra deres skæbne og flyder mellem identiteter. De vandrer omkring, snakker og tænker, digter og synger. Frigørelse har at gøre med cirkulation for Rancière; det er, når folk og ordene cirkulerer, at der sker noget, at politiordenens regulerede univers bryder sammen. Når folk skifter job eller er ude at gå, når folk snakker sammen, når de skriver sammen og derved opbløder grænsen mellem det offentlige og det private, når sang gør hverdagen til andet end hårdt arbejde. Det var derfor, at en anden af Rancières helte, snedkerfilosoffen Louis-Gabriel Gauny krævede, at alle havde råd til godt fodtøj. Det var vigtigt, at alle vagabonderer, da "gåture giver kraft til idéerne. $\ll^{45}$ At gå er at udfordre den hierarkiske distribution af kroppe og billeder. Når snedkerfilosoffen vandrer rundt omkring på må og få, bliver den naturlige reproduktion undergravet. Der opstår et mellemrum, et interval mellem ordene og kroppene, hvor det er muligt at undslippe virkeligheden og skabe en anden her og nu.

»Man kan således drømme om de frigjortes samfund, der vil være et kunstnersamfund. Et sådant samfund ville forkaste opdelingen mellem de, som ved, og de, der ikke ved, mellem de, som har, og de, som ikke har intelligensens ejendom. Det samfund ville kun anerkende aktive ånder: Mennesker, som agerer, som taler om de- 
res handlinger og derved forvandler alle deres værker til måder at signalere den menneskelighed, der er i dem og i alle. $\aleph^{46}$

\section{Noter}

1 Martyne Perrot og Martin de la Soudière: »Histoire des mots, mots de l'histoire" (interview med Jacques Rancière),in Communications 58 (1994), p. 87.

2 Alain Badiou: »Rancière et la communauté des égaux ", in Abrégé de métapolitique, Paris 1998, p. 121.

3 Davide Panagia: »Dissenting Words: A Conversation with Jacques Rancière«, Diacritics 2 (2000), p. 114. Rancière analyserer udsagnet »vi er alle tyske jøder « i flere af sine bøger, bl.a. Les noms de l'histoire. Essai de poétique du savoir, Paris 1992, pp. 196-197, og La mésentente. Politique et philosophie, Paris 1995, pp. 90-91.

4 Rancière: La mésentente, pp. 41-67.

5 Jvf. Kristin Ross: May '68 and its Afterlives, Chicago \& London 2002, pp. 22-25. Ross bruger på fremragende vis Rancières begreber til at analysere majrevolten med.

6 Jacques Rancière: La mésentente, p. 53.

7 Ibid.

8 Rancière: Les noms de l'histoire, p. 196.

9 Rancière: La leçon d'Althusser, Paris 1974, p. 9.

10 Denne kreds inkluderede, ud over Rancière, blandt andre Etienne Balibar, Régis Debray og Pierre Macheray. For en omhyggelig beskrivelse af det miljø, Rancière var en del af i 1960'erne, se Donald Reid: »Introduction «, The Nights of Labour: The Workers' Dream in Nineteenth-Century France, overs. John Drury, Philadelphia 1989, pp. xv-xxxvii. I introduktionen til La leçon d'Althusser diskuterer Rancière den samtidige debat før og efter maj ' 68.

11 Det er Althussers tekst »Théorie, pratique théorique et formation théorique. Idéologie et lutte idéologique" (som i samtiden cirkulerede i duplikerede eksemplarer, men er forblevet upubliceret på fransk), som Rancière underkaster analyse i »Sur la théorie de l'idéologie", in La leçon d'Althusser, pp. 227-277.

12 Op.cit., p. 238.

13 Op.cit., p. 240.

14 Karakteristisk for kommunistpartiets reaktion på majrevolten, krævede partiet - før gaullisterne gjorde det - at de venstreradikale bevægelser blev forbudt, og at Daniel Cohn-Bendit blev udvist til Tyskland. Jvf. Daniel Cohn-Bendit: Le gauchisme. Remède à la maladie sénile du communisme, Paris 1968.

15 Rancière: La leçon d'Althusser, p. 71.

16 Op.cit., p. 60.

17 For et eksempel på Althussers rent teoretiske analyse af historiske begivenheder, se »Contradiction et surdétermination", in Pour Marx, Paris 1965, pp. 85-116. For analyser af Althussers teori og en beskrivelse af den samtidige debat, se Gregory Elliot: Althusser: The Detour of Theory, London \& New York 1987, og Robert Geerlandt: Garandy et Althusser. Le débat sur l'bumanisme dans le Parti Communiste français et son enjeu, Paris 1978. 
18 Peter Hallward: »Jacques Rancière and the Subversion of Mastery«, in Paragraph 1 (2005), p. 26.

19 I »Althusser, Don Quichotte et la scène du texte « citerer Rancière fra Althussers forord til Live le Capital: »I historien om den menneskelige kultur risikerer vores tid at fremstå som kendetegnet ved den mest dramatiske og mest krævende af alle prøver: opdagelsen af og uddannelsen i de mest simple gestus: se, lytte, tale, læse - disse gestus som sætter menneskene i forbindelse med deres værker [œuvres] og fører disse værker tilbage til deres egne struber, dvs. deres 'fraværk af værk' ['absences d'œuvres']. « Louis Althusser: »Préface. Du Capital à la philosophie de Marx«, in Lire le Capital, Paris 1975 (org. 1965), p. 12. Citeret i Rancière: "Althusser, Don Quichotte et la scène du texte", in La chair des mots. Politique de l'écriture, Paris 1998, p. 157.

20 Louis Althusser: »Problèmes étudiants«, La Nouvelle Critique 152 (1964), p. 90. Citeret af Rancière i La leçon d'Althusser, p. 257.

21 Rancière: Le maître ignorant. Cinq leçons sur l'émancipation intellectuelle, Paris 1987, p. 167.

22 Op.cit., p. 33.

23 Jvf. Rancière: »Mode d'emploi pour une réédition de Lire le 'Capital'«, Les Temps modernes 328 (1973), pp. 788-807.

24 Rancière: Le philosophe et ses pauvres, Paris 1983, p. 195.

25 Op.cit., p. 169.

26 Op.cit., p. 116.

27 Karl Marx og Friedrich Engels: Det kommunistiske partis manifest, overs. Sven Brüel, København 1970 (org. 1848), p. 30 ff. Citeret af Rancière i Le philosophe et ses pauvres, p. 116.

28 Rancière: Le philosophe et ses pauvres, p. $124 \mathrm{ff}$.

29 Op.cit., p. 127.

30 Rancière kritiserer Bourdieu i flere af sine tekster, de mest udfoldede analyser findes i et kapitel af Le philosophe et ses pauvres, »Le sociologue roi«, pp. 239288, og i Rancières bidrag til anti-Bourdieu-antologien L'empire du sociologue, Paris 1984, pp. 13-36.

31 Rancière: "L'éthique de la sociologie«, L'empire du sociologue, p. 28.

32 Rancière: Le philosophe et ses pauvres, p. 266.

33 Alain Faure og Jacques Rancière (red.): La Parole ouvrière 1830-1851, Paris 1976, Rancière: La nuit des prolétaires. Archives du rêve ouvrier, Paris 1981, og Rancière: Les Scènes du peuple (Les Révoltes logiques, 1975-1985), Lyon 2003.

34 Rancière: La nuit des prolétaires, p. 9.

35 Rancière: Le partage du sensible, p. 52.

36 Rancière: Le maître ignorant, p. 147.

37 Solange Guénoun og James H. Kavanagh: »Jacques Rancière: Litterature, Politics, Aesthetics: Approaches to Democratic Disagreement «, in SubStance 92 (2000), p. 5.

38 Rancière: Le partage du sensible. Esthétique et politique, Paris 2000, p. 13.

39 Rancière: Les noms de l'histoire, p. 197.

40 Rancière: »Pouvoirs et strategies. Entretien avec Michel Foucault", in Les Révoltes logiques 4 (1977), p. 92. Rancière har flere steder skrevet om inspirationen fra Foucault senest i »L'héritage difficile de Michel Foucault «, in Chroniques des temps consensuels, Paris 2005, pp. 183-187. 
41 Éric Alliez: »Peuple ou multitude? Question d'Éric Alliez à Jacques Rancière«, in Multitudes 9 (2002), p. 95.

42 Jvf. Rancière: »Balzac et l'île du livre", in La chair des mots, pp. 124-127.

43 I La leçon d'Althusser skriver Rancière, at det, der undslipper Althusser, netop er »ordenes magt", op.cit., p. 177.

44 Jacques Rancière: La mésentente, p. 34.

45 Louis-Gabriel Gauny: »Diogène et saint Jean le Précurseur", in Rancière (red.): Le Philosophe plébéien, Paris 1983, p. 106.

46 Rancière: Le maître ignorant, p. $120 \mathrm{f}$. 